\title{
中心圧縮を受ける充填鋼管コンクリート柱の内部温度と耐火時間に関する研究 FIRE RESISTANCE OF CONCRETE-FILLED STEEL TUBE COLUMNS
UNDER CONSTANT AXIAL LOADS
}

\author{
齋藤秀人*, 森田 武**, 上杉英 樹*** \\ Hideto SAITO, Takeshi MORITA and Hideki UESUGI
}

\begin{abstract}
This paper presents both experimentally and analytically the fire-resistance of concrete-filled steel tube (CFT) columns without fireprotection. Six of CFT column specimens, with rectangular or circular sections of $300 \mathrm{~mm}$ to $500 \mathrm{~mm}$ in size, were heated for three hours in accordance with ISO-834. A transition of the temperatures measured inside of concrete was simulated successfully by the numerical thermal analysis, in which the thermal conductivity of concrete was taken as 0.8 times of the value prescribed in Eurocode 4 (EC4), and the specific heat of concrete taken as 1.2 times. Based on the numerical thermal analysis for the CFT columns, a non-linear stress analysis was carried out taking into account the under-high-temperature behaviors of concrete as prescribed in EC4. It turned out that, for the heating tests of the axially loaded CFT columns, the stress analysis could possibly explain the deviation in the previous experimental data by allowing a tolerance to the standard heating curves prescribed in ISO-834.
\end{abstract}

Keywords : fire resistance, concrete-filled steel tube columns, non-fire-protection, constant axial load 耐火性能，充填鋼管コンクリート柱，無耐火被㙏，一定軸力

1. はじめに

無耐火被覆の鉄骨柱が火災時に直接火炎にさらされると荷重支持 能力を早期に失う。充填鋼管コンクリート柱（以下 CFT柱）におい ても，外周部は高温となって早期に強度低下する。しかしコンク リートの内部温度はなかなか上昇せず, 柱の荷重支持能力は一定時 間維持される。耐火構造としての無耐火被覆 CFT柱は欧州では以前 から認められており ${ }^{1)}$ ，多くの実験結果に基づいて無耐火被覆 CFT 柱の実施例が我が国でも近年多く見られるようになってきている。

1977 年に齊藤・上杉は, 実験的・解析的に温度性状を検討した結 果を報告し2，3)，無耐火被覆 CFT柱実現の可能性を示した。1982年 以降，他に先駆けて古平らは載荷加熱試験結果を報告し4 7), 引き 続き佐久間 $5^{81}$ ・ 今野 $5^{9 \sim 10)} \cdot$ 池田 $5^{11)}$ ・作本 $5^{12,131} \cdot$ 道越ら

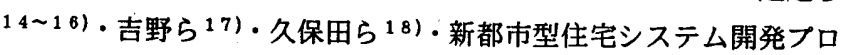
ジェクト(以下 新都市) 19) などにより様々な実験報告がなされて きた。一方筆者らは, 梁の伸び出しを考虑した無耐火被覆 CFT柱の 耐火性能に関する研究 $20 \sim 26)$ および無耐火被覆CFT柱の内部温度と 耐火性能 27)について 1992 年以降報告してきた。

無耐火被覆 CFT柱の耐火時間は, 鋼管を無視した軸力比（コンク リート断面積と圧縮強度の積で軸力を除した值)で一般に評価され， 設計手法も構築されてきた ${ }^{19)}$ 。しかし耐火試験装置固有の性能に試 験結果が影響を受けるためか，実験で得られた耐火時間には大きな バラッキが認められる。そこで試験条件の誤差を考虑して耐火時間
を評価する必要があると考えた。

本論は，無耐火被䧗CFT柱の内部温度を実用的に予測すること,お よび中心圧縮を受ける無耐火被覆CFT柱の耐火時間のバラッキの原

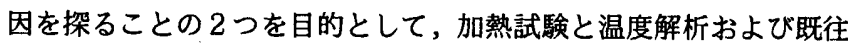
の試験結果4〜13,15〜19) の集積と温度・熱応力解析を試みたもので ある。

なお本研究でとった手法は, 純粋な理学的方法ではなく, 若干の 誤差をともなっても結果的に第一近似が得られるならばそれで良し とするエ学的方法である。コンクリートのように砂・砂利・セメン 卜・水の結合体である物質の高温性状を精密な分析的方法で追求す ることはきわめて困難であり，むしろ不可能であるからである。

\section{2. 無耐火被覆 CFT 柱の耐火試験時の内部温度}

\section{1 既往の研究}

無耐火被覆 CFT柱の温度性状に関しては，齋藤・上杉による研究 2,3) 以降, 今野ら ${ }^{10)}$ や道越ら 14)により実験的あるいは解析的研 究が行われ,柴田 ${ }^{28}$ )による解析的研究はコンクリート充填鋼管構造 設計施工指針 ${ }^{29)}$ にまとめられている。

高温強度・熱伝道率・比熱などの材料の高温特性についての研究 は以前から行われ30 32), 近年まとめられたものとしてはEurocode 4 (以下 EC4） ${ }^{33)}$ と建筑物の総合防火設計法（以下防火総プロ） ${ }^{34)}$ がよく知られている。

\footnotetext{
(注)本研究の一部は文献27)に発表している。

* 清水建設侏技術研究所主任研究員

** 清水建設(侏技術研究所 主任研究員 - 工博

*** 千葉大学大学院自然科学研究科教授. 工博
}

Senior Research Engineer, Institute of Technology, Shimizu Corporation Senior Research Engineer, Institute of Technology, Shimizu Corporation, Dr. Eng. Prof., Graduate School of Science and Technology, Chiba University, Dr. Eng. 


\section{2 加熱試験}

中心圧縮の載荷加熱試験は，様々な断面の試験体を対象として行 われている。しかし内部温度は詳細に報告されていない。そこで基 礎的な温度データを得ることを目的として加熱試験を行った。

試験体は，概略外形寸法が $300 ・ 400 \cdot 500 \mathrm{~mm}$ である角形断面と円 形断面で，長さ $1,150 \mathrm{~mm}$ の 6 体である。長さ方向中央付近の 1 断面 で温度測定を行い，図ー1に示すように断面の中心で 1 点，その他で は対称条件を渵たす各 4 点を測点とし，角形断面のコーナー部には 熱電対を多く配した。コンクリートは呼び強度 $42 \mathrm{~N} / \mathrm{mm}^{2}$, 鋼管は F 値 325N/mm 22である。試験時のコンクリートの材令は 114 〜 118 日， 任縮強度 $54.3 \mathrm{~N} / \mathrm{mm}^{2}$, 含水率 $4.9 \%$ であった。コンクリートの調合・ まだ固まらないコンクリートの試験結果・圧縮試験結果を表ー1〜3 に示す。

試験は，清水建設（株）の耐火試験炉において，概略外形寸法が 同じ角形と円形を 2 体づつ図一2に示すように垂直にセットして実施 した。なお断熱を目的として, 試験体の上下端部約 $10 \mathrm{~cm}$ および上 面には毛布状の耐火被覆を施した。加熱はISO 834 ${ }^{35}$ )に定める標準 加熱 3 時間である。温度測定には K 熱電対を用い, 加熱終了後も 3 時 間程度の計測を行った。その結果, 炉内温度は標準加熱温度曲線に ほほ一致し,対称条件を満たす各4測点での内部温度には大きなバラ ツキは認められなかった（図ー7・8参照）。

\section{3 温度解析}

内部温度解析は, 加熱温度・熱伝達率・材料の熱定数・コンクリー 卜の含有水分の取扱いを定め，有限要素法あるいは差分法により一 般に行われる。本論では，角形断面に対しては $1 / 4$ 断面を対象にした
二次元差分法, 円形断面に対しては一次元差分法を用いた。第 $i-1$ 首（温度 $T_{i-1}$, 熱伝導率 $\lambda_{i-1}$ ，層厚 $d_{i-1}$ ） 加第 $i$ 層（温度 $T_{i}$, 熱伝 導率 $\lambda_{i}$ ，層厚 $\left.d_{i}\right)$ に面積 $\left(A_{i}\right)$ を通して微小時間 $(\Delta t)$ に流入す る熱量 $\left(q_{i}\right)$ の一次元差分式を 1 式に，第 $i$ 層（比熱 $C_{i}$ ，密度 $\rho_{i}$ ， 体積 $\left.V_{i}\right)$ の微小時間 $(\Delta t)$ の温度上昇 $\left(\Delta T_{i}\right)$ を 2 式に示す ${ }^{34)}$ 。

$$
\begin{aligned}
& q_{i}=\frac{2 \cdot\left(\lambda_{i-1} \cdot d_{i-1}+\lambda_{i} \cdot d_{i}\right)}{\left(d_{i-1}+d_{i}\right)^{2}} \cdot\left(T_{i-1}-T_{i}\right) \cdot A_{i} \cdot \Delta t \\
& \Delta T_{i}=\frac{q_{i}-q_{i+1}}{C_{i} \cdot \rho_{i} \cdot V_{i}}
\end{aligned}
$$

図ー3に示すように，鋼管を厚さ方向に 3 分割 $(d / 4 \cdot d / 2 \cdot d / 4, d$ : 厚さ）し，コンクリートは中心から $5 \mathrm{~mm} \cdot 10 \mathrm{~mm} \cdot 10 \mathrm{~mm} \cdot \cdots$ と分 割して，鋼管と接する部分で端数を調整することとした。設定した 諸条件は次の通りである。

加熱温度は, 昇温過程ではISO 834 の標準加熱曲線, 冷却過程では 3 回の加熱試験で得られた炉内温度実測値の近似曲線とする。

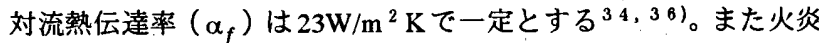
の等価放射率 0.9 ・鋼の放射率 0.8 ・合成放射率 $\left(\varepsilon_{r}\right) 0.73$ とし ${ }^{36)}$, ステファン・ボルッマン定数 $(\sigma)$ を用いて放射熱伝達率は温度に 依存させる。火炎 (温度 $T_{f}$ ) から第 1 層 (温度 $T_{1}$, 面積 $A_{1}$ ) に微小 時間 $(\Delta t)$ に流入する熱量 $\left(q_{1}\right)$ を3 式に示す ${ }^{34}$ 。

$$
q_{1}=\left\{\alpha_{f} \cdot\left(T_{f}-T_{1}\right)+\varepsilon_{r} \cdot \sigma \cdot\left(T_{f}^{4}-T_{1}^{4}\right)\right\} \cdot A_{1} \cdot \Delta t
$$

鋼材とコンクリートの比熱・熱伝導率は, 図一4に示すように防火 総プロとEC4には一見して大きな差はない。しかし防火総プロの適 用範囲は EC4に比較して極めて狭い。すなわち EC4の適用範囲が常
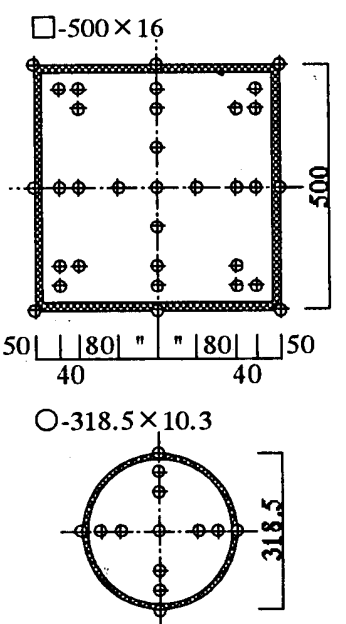

39.

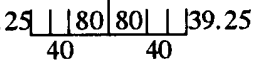

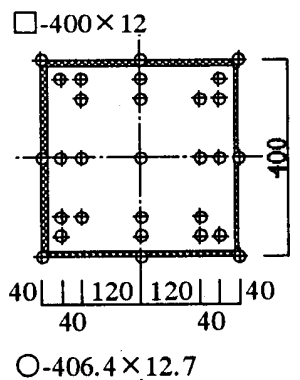

$0-406.4 \times 12.7$

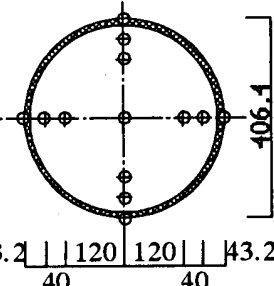

40

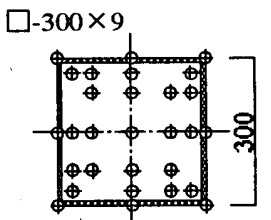

$\frac{30 \bigsqcup\lfloor 80 \mid 80 \bigsqcup \bigsqcup 30}{40}$

$0-508 \times 12.7$

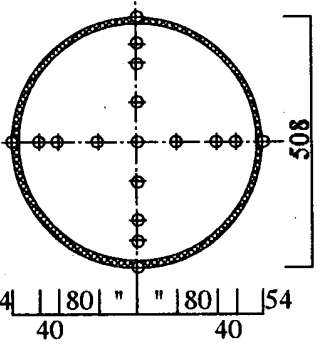

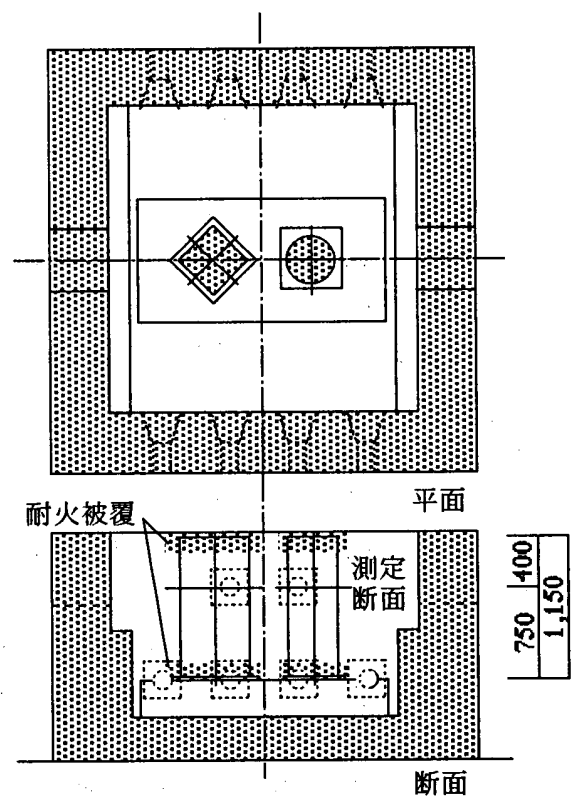

図一２耐火試験炉と試験体

\begin{tabular}{|c|c|c|c|c|c|c|c|c|}
\hline \multirow{2}{*}{$\begin{array}{c}\text { Sl. } \\
(\mathrm{cm})\end{array}$} & \multirow{2}{*}{$\begin{array}{l}\text { Air } \\
(\%)\end{array}$} & \multirow{2}{*}{$\begin{array}{l}\text { W/C } \\
(\%)\end{array}$} & \multirow{2}{*}{$\begin{array}{l}\text { S/a } \\
(\%)\end{array}$} & \multicolumn{5}{|c|}{ 单位量 $\left(\mathrm{kg} / \mathrm{m}^{3}\right)$} \\
\hline & & & & W & $\mathrm{C}$ & $\mathrm{S}$ & $\mathrm{G}$ & Ad. * \\
\hline 21 & 4.5 & 38.9 & 46.2 & 175 & 450 & 773 & 927 & 6.075 \\
\hline
\end{tabular}

図-1 試験体の断面と温度測定位置，

表ー 1 コンクリートの調合

表ー 2 まだ固まらないコンクリートの試験結果

\begin{tabular}{c|c|c|c|c}
\hline $\begin{array}{c}\mathrm{SI} \\
\mathrm{cm}\end{array}$ & $\begin{array}{c}\text { Air } \\
\%\end{array}$ & $\begin{array}{c}\text { 温度 } \\
{ }^{\circ} \mathrm{C}\end{array}$ & $\begin{array}{c}\rho \\
\mathrm{kg} / \mathrm{m}^{3}\end{array}$ & $\begin{array}{c}\text { 気温 } \\
{ }^{\circ} \mathrm{C}\end{array}$ \\
\hline 22.5 & 7.4 & 11.0 & 2300 & 6.5 \\
\hline
\end{tabular}

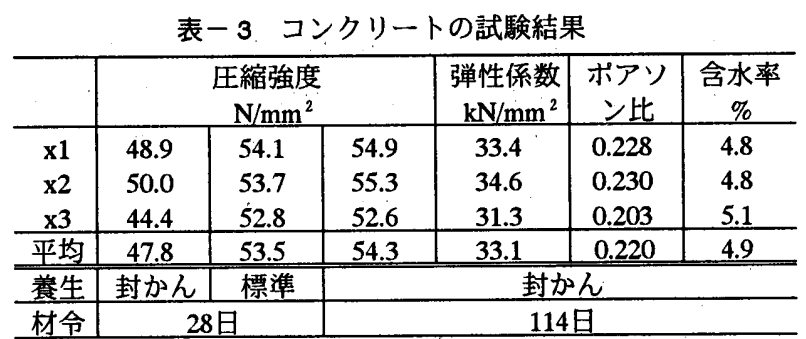


温から $1200^{\circ} \mathrm{C}$ までであるのに対し, 防火総プロの適用範囲は鋼材が $600^{\circ} \mathrm{C}$ 以下, コンクリートが $800^{\circ} \mathrm{C}$ 以下に限られ外挿が必要になる。 そこで本論で用いる熱定数は EC4に準拠することとした。

コンクリートの含有水分は移動せず，100 $\mathrm{C} て ゙$ 蒸発し, 水分がある 間は温度上昇しないと仮定する。含水率は $4.9 \%$ とした。水の蒸発潜 熱 $\left(H_{b}\right)$ による第 $i$ 層の水分蒸発量 $(\Delta W)$ を 4 式に示す ${ }^{44)}$ 。

$$
\Delta W=\frac{q_{i}-q_{i+1}}{H_{b}}
$$

比重は，鋼材 $7850 \mathrm{~kg} / \mathrm{m}^{3}$ ・コンクリート $2300 \mathrm{~kg} / \mathrm{m}^{3}$ で一定とする。 昇温過程でのコンクリート温度の解析值と実測值の比較を図ー5に 示す。断面形状に関係なく, 解析結果は測定結果を大きく上回る傾 向が認められる。これは安全側の設計(高い内部温度)を意図し,EC4 が高い熱伝導率と低い比熱をコンクリートに設定しているためであ ると考えられる。

そこで内部温度の解析值を実用的な水準まで実測值に近づけるこ
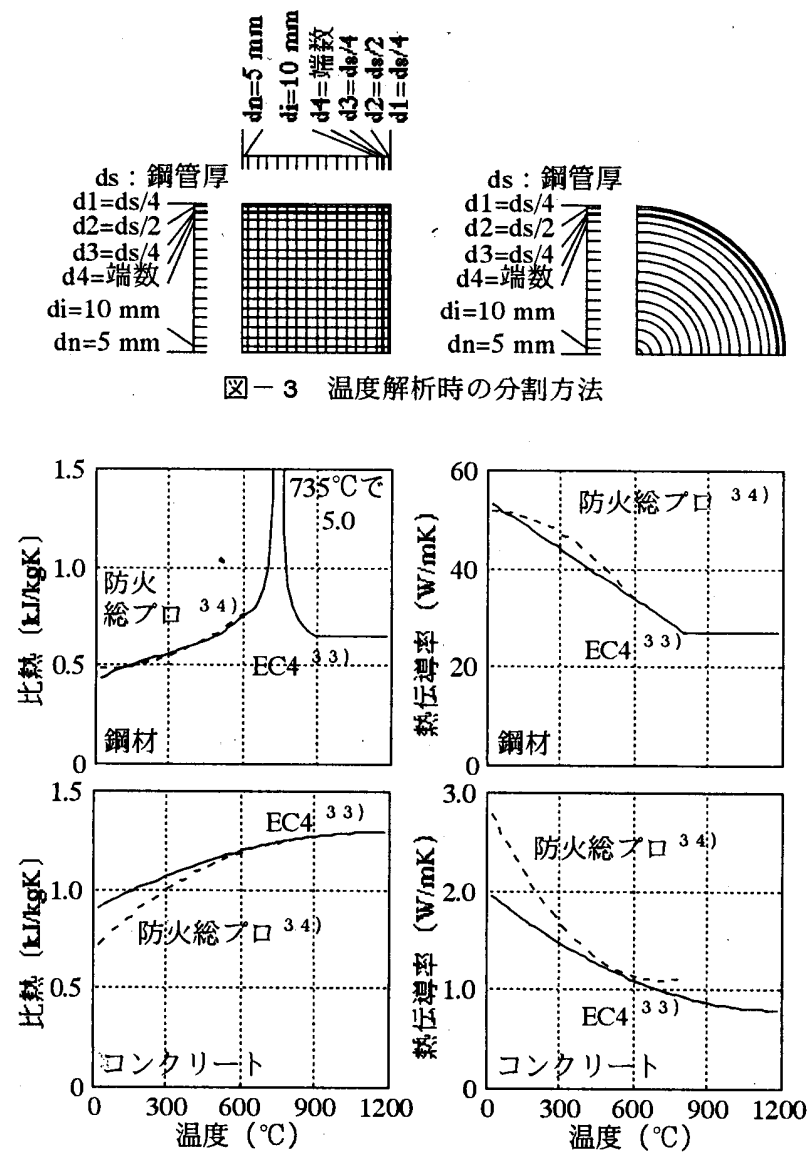

図ー4＼cjkstart鋼材とコンクリートの熱常数
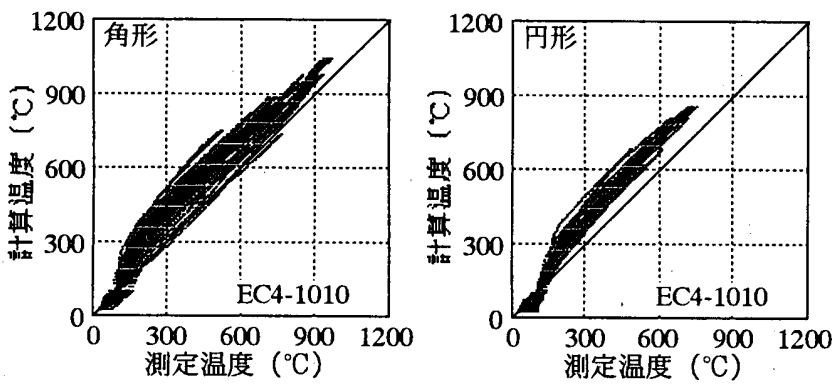

図一 5 測定值と計算值の比較
とを目的として $\mathrm{EC} 4$ のコンクリ一トの熱伝導率に 0.8 と 0.6 , 比熱 に 1.2 と 1.4 を乗じ, 同様の温度解析を行った。解析值を実測值で除 した值を横軸とし, 縦軸を度数として図ー6に示す。図中， $\mathrm{x}$ は平均 值，のは標準偏差である。コンクリートの熱定数としては，EC4の 熱伝導率に 0.8 ・比熱に 1.2 を乗じた解析結果が最適である。

コンクリートの熱伝導率を EC4の0.8 倍, 比熱をEC4の 1.2 倍, 鋼 材の熱定数をEC4とした温度解析結果を, 時刻歴の温度測定結果 (炉 内・鋼管表面・内部）に上書きして図 $-7 \cdot 8$ に示す。解析結果と測 定結果は非常に良く一致している。

\section{4 他事例への温度解析の適用}

コンクリートの調合と強度が前記と異なるCFT柱への温度解析の 適用性を確認するために，既報のCFT柱の載荷加熱試験2 2) の試験 体について同様の温度予測を行い測定温度と比較する。

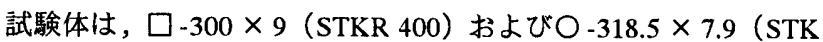
400）各 6 体の鋼管に鉄筋を配しコンクリートを充填した 12 体であ
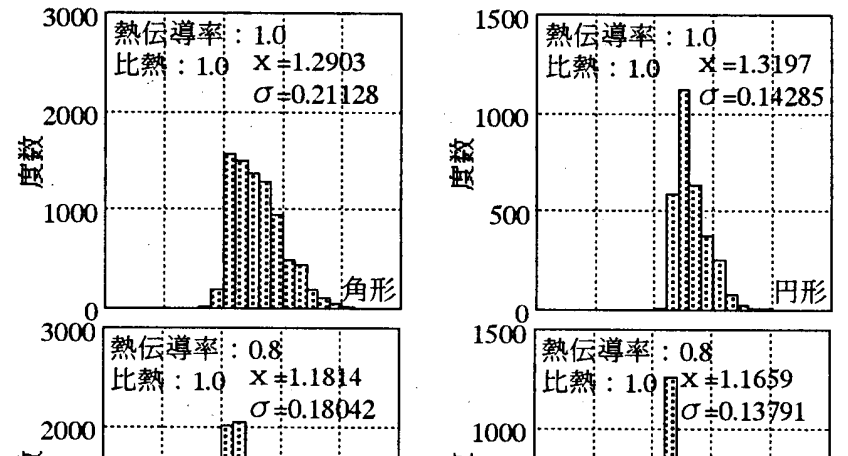

些

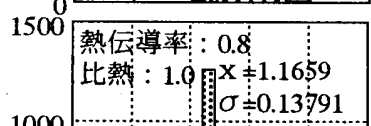
100

些
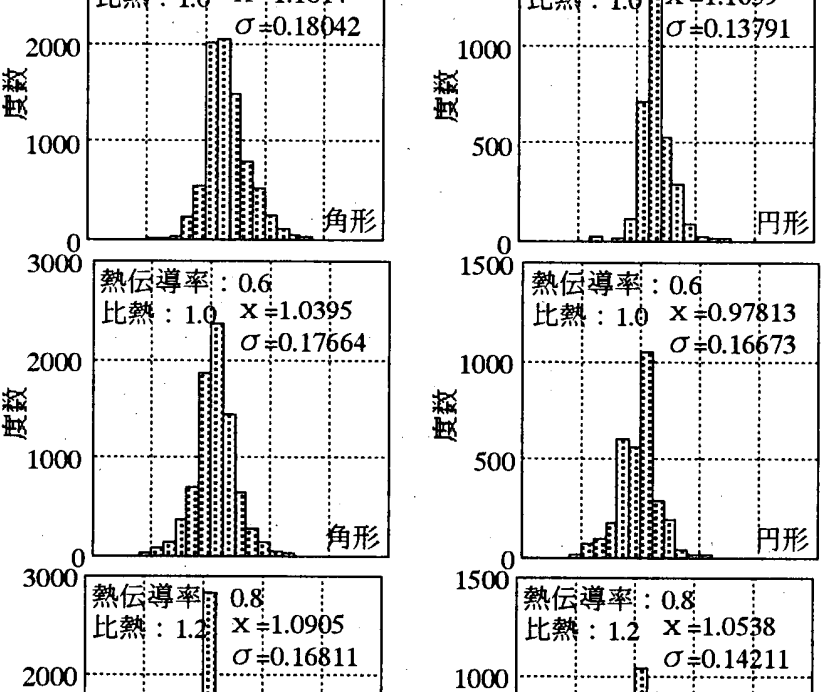

乿

(1)

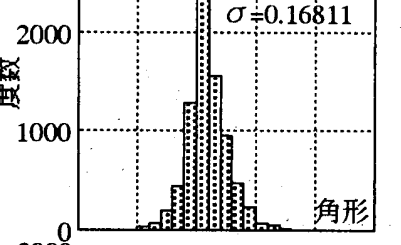

500

導率: : 0

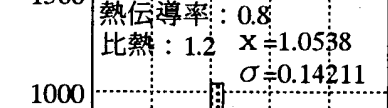

些

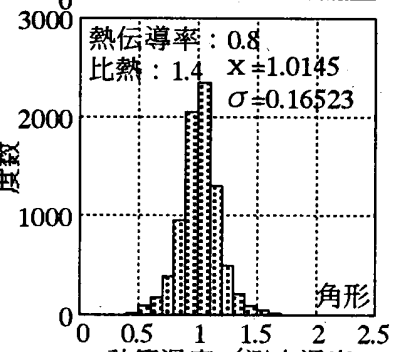

計算温度 /測定渴度

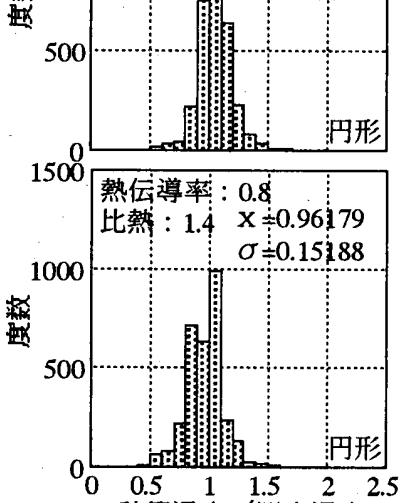

困ー6 コンクリートの熱常数を変化させた温度解析結果 

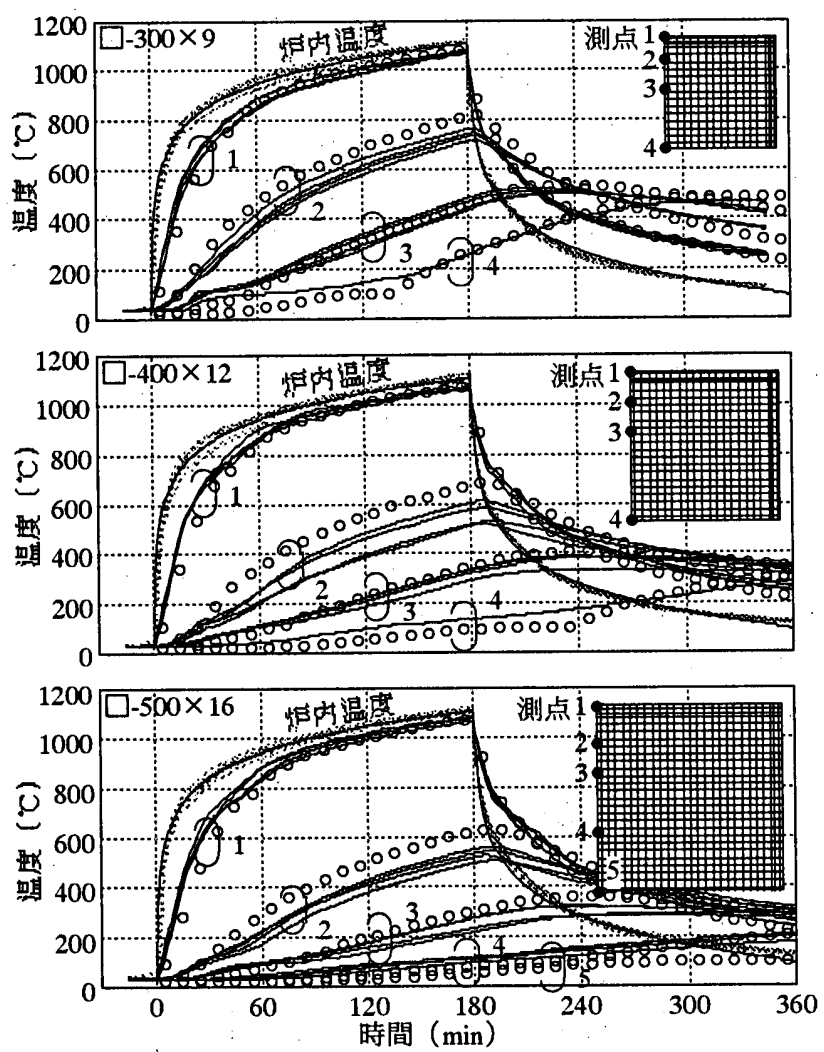

図-7 温度測定值と計算値の時刻歴（角形断面）
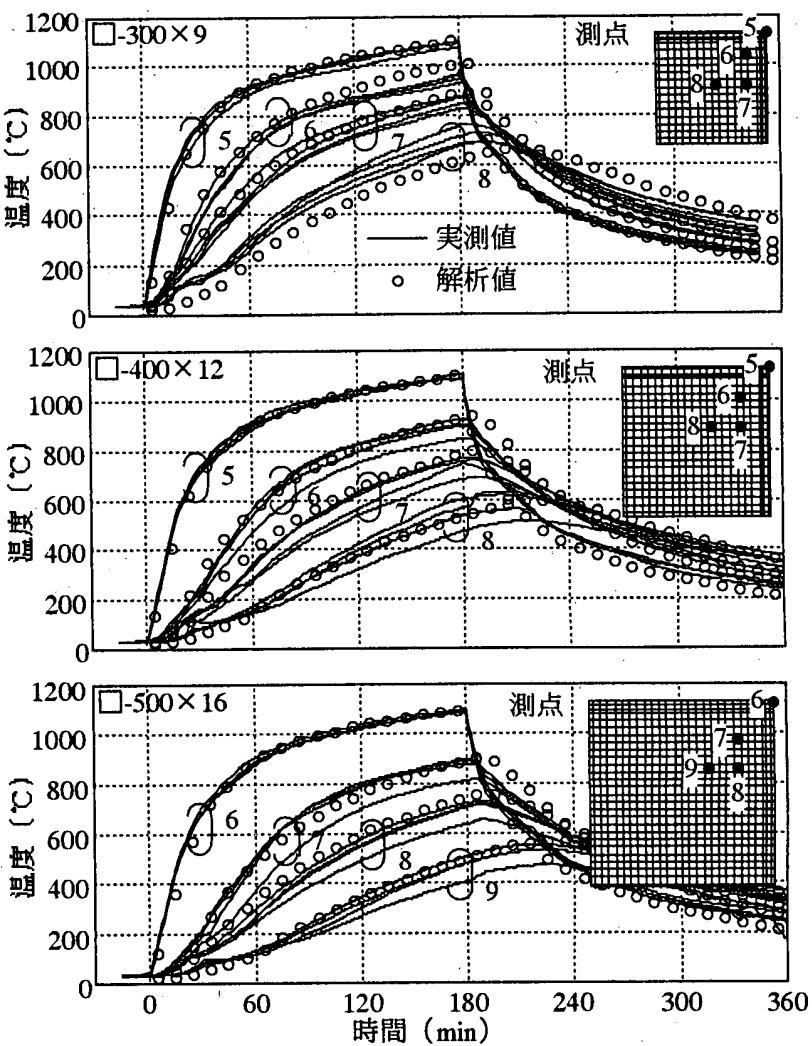
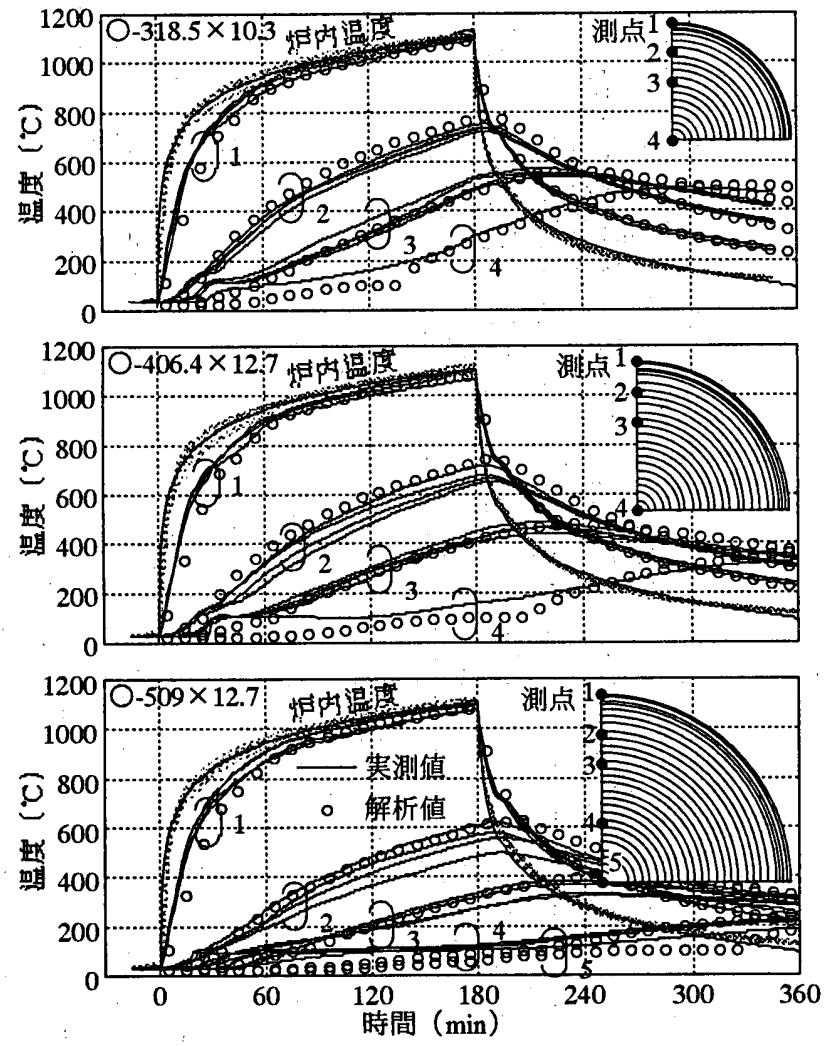

図-8 温度測定值と計算值の時刻歴（円形断面）

る。試験は 2 期にまたがるが，コンクリートの呼び強度は共に $30 \mathrm{~N} /$ $\mathrm{mm}^{2}$ であり，表ー4に示す 2 種の調合はほほ同じである。試験体に は図ー9に示すように長さ $1.2 \mathrm{~m}$ の筒体部が 2 つあり，その片方を無
耐火被覆の加熱試験部とし，加熱試験部以外には十分な耐火被輹を 施した。温度測定は加熱試験部の中央断面において行った。温度解 析に対応する測定位置を図一10に示す。

試験では，熱膨張による梁の伸び出しを考慮した変形を軸力とと もにCFT 柱に作用させて，軸力を保持できなくなるまで JIS A 1304 37)の標準加熱を行った。試験時のコンクリートの材令は59〜88日， 圧縮強度 $31.0 \sim 37.0 \mathrm{~N} / \mathrm{mm}^{2}$, 含水率 $6.0 \sim 6.5 \%$ あった。

温度解析は前述と同様に,角形断面に対しては $1 / 4$ 断面を対象にし た二次元差分法，円形断面に対しては一次元差分法を用いた。鋼管 を厚さ方向に 3 分割 $(\mathrm{d} / 4 \cdot \mathrm{d} / 2 \cdot \mathrm{d} / 4, \mathrm{~d}$ : 厚さ) し, コンクリートは 中心から $5 \mathrm{~mm} \cdot 10 \mathrm{~mm} \cdot 10 \mathrm{~mm} \cdot \cdots$ と分割して，鋼管と接する部分 で端数を調整している。設定した諸条件は次の通りである。

加熱温度は JIS A 1304 の標準加熱曲線とする。

対流熱伝達率は $23 \mathrm{~W} / \mathrm{m}^{2} \mathrm{~K}$ で一定とする。また火炎の等価放射率 0.9 ・鋼の放射率 0.8 ・合成放射率 0.73 とし，ステファン・ボルッマン 定数を用いて放射熱伝達率は温度に依存させる。

コンクリートの熱伝導率はEC4の0.8倍, 比熱はEC4の 1.2倍とし， 鋼材の熱定数は EC4 とする。

コンクリートの含有水分は移動せず, $100^{\circ} \mathrm{C} て ゙$ 蒸発し, 水分がある 間は温度上昇しないと仮定する。含水率は $6.0 \%$ とした。

比重は，鋼材 $7850 \mathrm{~kg} / \mathrm{m}^{3}$ ・コンクリート $2300 \mathrm{~kg} / \mathrm{m}^{3}$ で一定とする。 温度解析結果を時刻歴の温度測定結果 (炉内・鋼管表面・内部) に 上書きして図ー 11 に示す。また図一 6 と同様に, 解析值を実測值で 除した值を横軸とし，縦軸を度数として図ー12に示す。図中， $\mathrm{x}$ は 平均值， $\sigma$ は標準偏差である。

載荷加熱試験では，コンクリートのひびわれによる熱電対の損傷 やひびわれでの水蒸気の移動があるためか，温度測定結果にバラッ 
キが認められる。また標準偏差も図ー6に比較して大きい。しかし度 数分布を見ると解析結果と测定結果は概わ良く一致しており, 2.2 節 とは異なる調合と強度のコンクリートを用いた CFT 柱においても， コンクリートの熱伝導率をEC4の0.8倍とし, 比熱を EC4の 1.2 倍と した温度解析は十分実用的であることを確認できた。

\section{3. 中心圧縮を受ける無耐火被覆 CFT 柱の耐火時間}

\section{1 既往の研究}

火災は構造物の長期荷重状態で発生する。CFT柱には常時, 曲げ モーメントとせん断力も作用しているが，軸力が支配的である ${ }^{38) 。}$ したがって中心圧縮の載荷加熱試験は，無耐火被覆 CFT柱の耐火時 間を確認する上で最も基本となる手段である。

無耐火被覆 CFT柱の中心載荷加熱試験は, 古平ら 4 ７) が開始し， 新都市 ${ }^{19)}$ をはじめ多くの実験報告8 13,15１8）が大断面卢高強度 材料を用いるなどしてなされてきた。

鉄筋などが配されていない既往の試験結果の一覧を表ー5に示す。 全59体中, 円形断面の試験体が 17 体とやや少ない。試験体の断面の 形状・寸法，コンクリート強度などは多様である。

中心圧縮を受けるCFT柱の耐火性能は鋼管を無視した軸力比で評 価されることが多い。そこで表一5の軸力比と耐火時間の関係を断面 形状別に図ー13に示した。図中の実線と点線は,コンクリート強度 $42 \mathrm{~N} / \mathrm{mm}^{2}$ 以下を対象とした新都市の回㷌式と設計式である。試験体 の断面寸法をプロットサイスで示し，白抜きのプロットは $42 \mathrm{~N} / \mathrm{mm}^{2}$ を越える高強度コンクリートの結果である。全体の傾向を回畄式は

\begin{tabular}{|c|c|c|c|c|c|c|c|c|c|}
\hline \multicolumn{10}{|c|}{ 表-4 } \\
\hline 区 & Sl. & Air & $\mathrm{W} / \mathrm{C}$ & S/a & \multicolumn{5}{|c|}{ 単位量 $\mathrm{kg} / \mathrm{m}^{3}$} \\
\hline 分 & $\mathrm{cm}$ & $\%$ & $\%$ & $\%$ & $\mathrm{~W}$ & $\mathrm{C}$ & $\mathrm{s}$ & G & Ad. \\
\hline $\mathrm{Cl}$ & 15.0 & 4.5 & 51.6 & 45 & 165 & 320 & 815 & 1017 & 0.8 \\
\hline $\mathrm{C} 2$ & 15.0 & 4.5 & 52.0 & 45 & 165 & 318 & 818 & 1017 & 0.8 \\
\hline
\end{tabular}

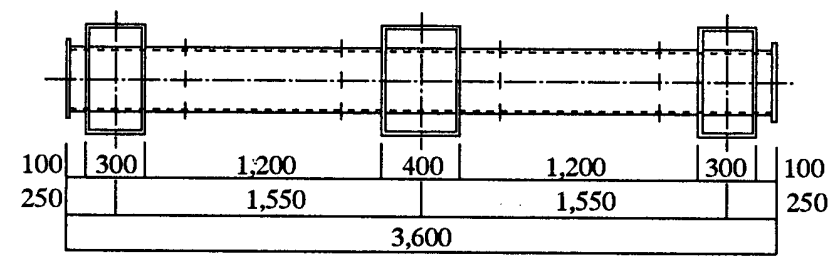

図ー9 試験体の形状寸法

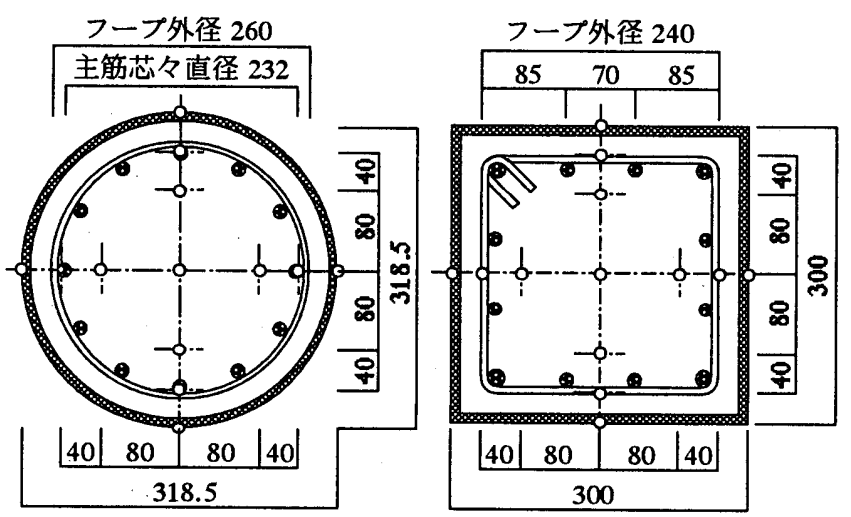

図一 10 試験体の温度測定位置（O印）
よく表している。しかし評価尺度である軸力比が同じであっても， 著しく異なる耐火時間が散見されている。42 $/ \mathrm{mm}^{2}$ 以下の角形断面

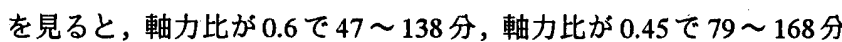
の耐火時間となっている。断面寸法や強度が異なる試験体の耐火時 間を, コンクリートの断面積と圧縮強度の積で軸力を除した軸力比 は評価できていない。

\section{2 解析的検討}

表一5の耐火時間の比較検討を目的として,同一の解析条件の下で 各試験体の耐火時間の算定を試みる。

前述と同様に内部温度は, 加熱をISO 834 の標準加熱曲線, コンク リートの熱伝導率を EC4の 0.8 倍，比熱を EC4の 1.2 倍とし，鋼材の 熱定数を EC4 として，一・二次元差分法で解析した。分割も前述と 同様で，鋼管は厚さ方向に 3 分割 $(d / 4 \cdot d / 2 \cdot d / 4, d:$ 厚さ) し, コ ンクリートの分割は中心から $5 \mathrm{~mm} \cdot 10 \mathrm{~mm} \cdot 10 \mathrm{~mm}$ ・・として，鋼

管と接する部分で端数を調整した。

耐火時間の解析值は，温度解析と同様に断面分割した単位長さの 部材を対象に, 弾塑性熱応力解析 $23 \sim 26,39,40)$ で求めた。温度は 前記解析值である。鋮管の存在は完全に無視し、コンクリートの熱 膨張率・高温強度低下率・応力ひずみ関係は図ー14に示すEC4にし たがった。クリープと過渡ひずみは考虑していない。

耐火時間の解析値を表一5の右欄に，耐火時間の実験値と解析値の 比較を図ー 15 に示す。試験体の断面寸法をプロットサイスで示し， 白抜きのプロットは高強度コンクリートである。解析值を著しく下 回る角形大断面・高強度の実験值 ${ }^{16)}$ が認められる。その他は, 実験
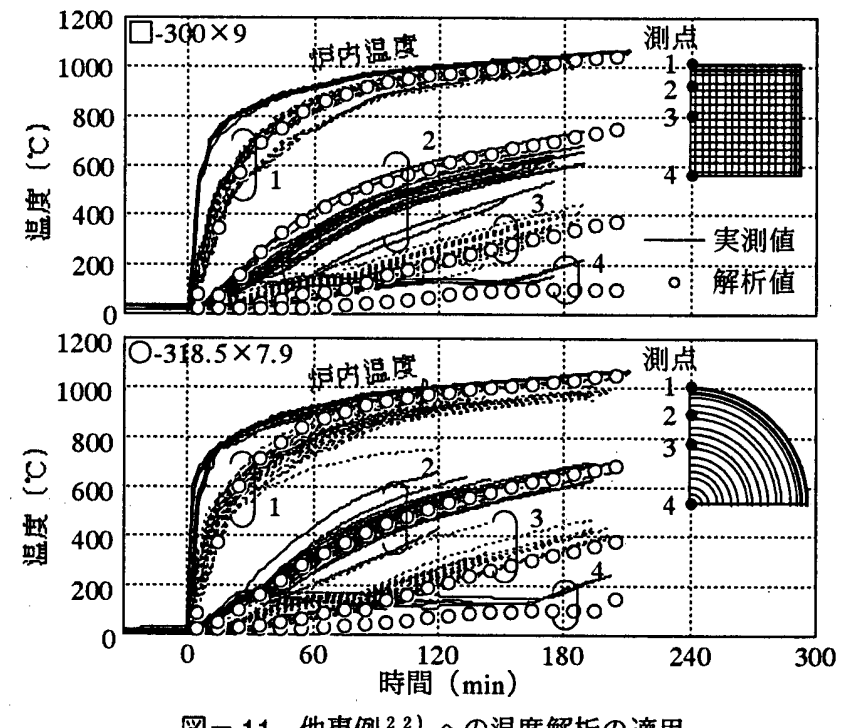

図-11 他事例 22) への温度解析の適用
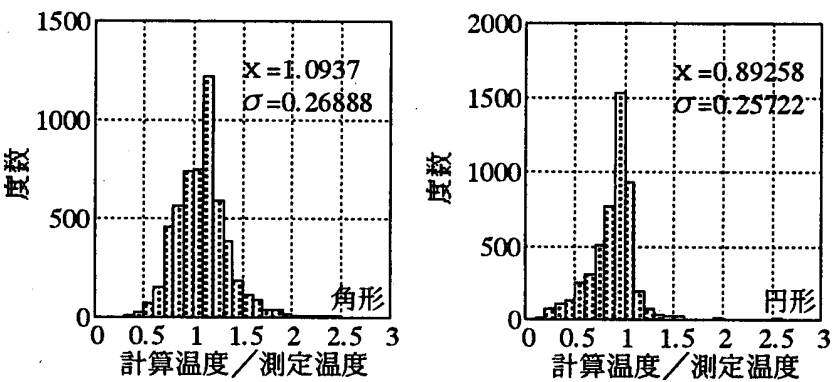

図-12 他事例 $\left.{ }^{2} 2\right)$ での温度解析結果の度数分布 
値と解析値が倍・半分程度に分布している。

実験には誤差が付き物である。無耐火被覆 CFT柱の中心載荷加熱 実験においても，支持条件・載荷荷重・加熱温度・コンクリート強 度などに誤差が考えられる。しかし，支持条件・載荷荷重・コンク リート強度などには許容誤差に関する規定が無い。一方でISO 834 は 加熱温度の許容誤差を次のように明記している。

「標準加熱温度に対する平均炉内温度の許容誤差は, 加熱5～10分 で $15 \% \cdot 10 \sim 30$ 分で $15 \sim 5 \% \cdot 30 \sim 60$ 分で 5〜2.5\%・60 分以上 で $2.5 \%$ あるると。さらに平均炉内温度が許容範囲内にある場合， 測定加熱温度と標準加熱温度の誤差を $100^{\circ} \mathrm{C}$ 未満とすること。」

表一 5 既往の試験結果

\begin{tabular}{|c|c|c|c|c|c|c|c|c|c|}
\hline No. & 鋼 管 & 鋼種 & $\begin{array}{c}\sigma \mathrm{B} \\
\mathrm{N} / \mathrm{mm}^{2}\end{array}$ & $\begin{array}{c}\text { 加熱 } \\
\text { 長さ } \\
\mathrm{m} \\
\end{array}$ & \begin{tabular}{|l|} 
徍長 \\
さ比
\end{tabular} & $\begin{array}{c}\text { 軸力比 } \\
\frac{\mathrm{P}}{\mathrm{Ac} \sigma \mathrm{B}}\end{array}$ & \begin{tabular}{|c} 
耐灭 \\
時間 \\
min
\end{tabular} & $\begin{array}{c}\text { 解析 } \\
\text { 值 } \\
\text { min }\end{array}$ & $\begin{array}{l}\text { 文献 } \\
\text { No. }\end{array}$ \\
\hline 1 & $-300 \times 9$ & SS41 & \begin{tabular}{|l|}
27.5 \\
\end{tabular} & & & \begin{tabular}{l|l|}
0.452 \\
\end{tabular} & \begin{tabular}{|l|}
106 \\
\end{tabular} & \begin{tabular}{|l|}
154 \\
\end{tabular} & 4,19 \\
\hline 2 & $\square-200 \times 6$ & & 28.3 & & & 0.44 & 88 & 85. & 4,19 \\
\hline 3 & $\square-300 \times 6$ & KR41 & 23.5 & 1.0 & & 0.50 & 172 & 130 & 8 \\
\hline$\underline{4}$ & $-300 \times 6$ & & 23.5 & 1.0 & & & 42 & 40 & 8 \\
\hline 5 & $0-150 \times 4.5$ & STK41 & 23.9 & & & 0.56 & 58 & 43 & 9 \\
\hline 6 & $\square-300 \times 9$ & 841 & 23.4 & 1.68 & & 0.94 & 30 & 17 & 5,19 \\
\hline 7 & $-300 \times 9$ & 541 & 23.4 & 1.68 & & 0.47 & 203. & 142 & 5,19 \\
\hline 8 & $\square-300 \times 9$ & 41 & 49.1 & 1.68 & & 0.45 & 157 & 151 & 5,19 \\
\hline & $\square-300 \times 9$ & 41 & 49.1 & 1.68 & & 0.34 & 248 & 203 & 5,19 \\
\hline 0 & $0-508 \times 6.4$ & 41 & $402 *$ & 2.2 & & 0.78 & 48 & 83 & 11 \\
\hline & $0-508 \times 6.4$ & 841 & $402 *$ & 2.2 & & .79 & 30 & 79 & 11 \\
\hline & $0-508 \times 6.4$ & 541 & 39.4 & 2.2 & & 0.79 & 22 & 79 & 11,19 \\
\hline 3 & $0.508 \times 6.4$ & $\$ 41$ & $402 *$ & 2.2 & & 0.79 & 25 & 79 & 11 \\
\hline & $0.508 \times 6.4$ & S41 & $402 *$ & 2.2 & & 0.51 & 144 & 282 & 11 \\
\hline 5 & $0.300 \times 9$ & $\mathrm{FR}$ & $346 *$ & 1.6 & & .30 & 177 & 223 & 12 \\
\hline & $\square-300 \times 9$ & FR & $346 *$ & 1.6 & & 0.43 & 83 & 159 & 12 \\
\hline 17 & $-300 \times 9$ & $\mathrm{FR}$ & $346 *$ & 1.6 & & .60 & 47 & 93 & 12 \\
\hline & $\square-300 \times 9$ & SS41 & 41.8 & 1.4 & & .60 & 47 & 93 & 6 \\
\hline 19 & $\square-300 x$ & & 41.8 & 1.4 & & 0.45 & 79 & 151 & 6 \\
\hline 0 & $\square-300 \times 9$ & SS4 & 41.8 & 1.4 & & 0.34 & 175 & 202 & 6 \\
\hline 21 & $\square-300$ & FR & 7.5 & 3.0 & & 68 & 33 & 70 & 13 \\
\hline 2 & $\square-300 \times 9$ & STK & 41.1 & & 3 & 48 & 72 & 141 & 10,19 \\
\hline 23 & $\square-3002$ & & 3.6 & 2.1 & & 0.33 & 207 & 205 & 17 \\
\hline 41 & - $300 \times 9$ & & 3.6 & 2.1 & & 39 & 139 & 178 & 17 \\
\hline 5$]$ & $\square-300$ & & 33.6 & 2.1 & & 50 & 82 & 131 & 17 \\
\hline 5 & $\square-300 \times 9$ & STK & 33.6 & 2.1 & & 0.66 & 27 & 72 & 17 \\
\hline 27 & प-300x & STK & 60.2 & 2.1 & & 0.38 & 101 & 183 & 17 \\
\hline & ㅁ-3002 & SM4 & 91.3 & 2.3 & & .31 & 115 & 219 & 15 \\
\hline 29 & $\square-250 \times 6$ & & 632* & 0.95 & & 45 & 42 & 120 & \\
\hline 30 & 0.26 & & $632 *$ & 0.95 & & 45 & 34 & 126 & 7 \\
\hline 31 & $0-31$ & & 5.5 & & & 66 & 47 & 77 & 18 \\
\hline 32 & $\square-500$ & STK & & & & 24 & 348 & 560 & 16 \\
\hline 33 & - -500 & & 0.2 & & & 0.35 & 102 & 413 & 16 \\
\hline 34 & -500 & & 70.2 & & & 55 & 36 & 207 & 16 \\
\hline 35 & $\square-50$ & & 0.2 & & & 35 & 206 & 468 & 16 \\
\hline 36 & D-7 & & & & 4.8 & & 323 & 1175 & 16 \\
\hline 37 & $\square-75$ & & 72.9 & & & 27 & 157 & 1073 & 16 \\
\hline 38 & $\square-750$ & & 75.7 & & & & 105 & 842 & 16 \\
\hline 39 & $\square-75$ & & 72.9 & & 4.8 & 0.55 & 41 & 424 & 16 \\
\hline 40 & $0-3$ & & 3.9 & 1.6 & & 0.79 & & 47 & 19 \\
\hline 41 & $0-3$ & & 40.2 & 16 & & 0.53 & 90 & 125 & 19 \\
\hline 42 & O-3 & & & 1.6 & & 79 & 3. & 47 & 19 \\
\hline 43 & & & & & & & & 103 & 19 \\
\hline 44 & $0-2$ & & .2 & 1.0 & 25 & 51 & 117 & 76 & 19 \\
\hline 45 & & & & & & & & 149 & 19 \\
\hline 46 & O- & & & 2.0 & & 87 & 2 & 38 & 19 \\
\hline 47 & & & & & & & & 24 & 19 \\
\hline 48 & $\square-3$ & & 23.9 & 1.6 & & 0.60 & 138 & 93 & 19 \\
\hline 49 & $\square-30$ & & & 1.6 & & & 168 & 151 & 19 \\
\hline 50 & $\square-30$ & & 40.2 & 1.6 & 8.17 & 0.60 & 58 & 93 & 19 \\
\hline 51 & $\square-30$ & & & 1.6 & & & & 25 & 19 \\
\hline 52 & {$[\square-20$} & & 40.2 & 1.0 & 8.25 & 0.45 & 132 & 81 & 19 \\
\hline 53 & $\square-20$ & & 40.2 & & & 0.60 & 79 & DS & 19 \\
\hline 54 & प & & 40.2 & 2.0 & 7.63 & 0.60 & 79 & 146 & 19 \\
\hline 55 & & & 40.2 & 2.0 & & & & & 19 \\
\hline 56 & $0-31$ & & 64.5 & 1.6 & 8.17 & 0.53 & 50 & 125 & 19 \\
\hline 57. & & & 64.5 & 1.6 & & 0.79 & 3 & & 19 \\
\hline 58 & $\square-30$ & & 64.5 & 1.6 & 8.17 & 0.60 & 32 & 93 & 19 \\
\hline 59 & $-300 \times 9$ & SM50A & 64.5 & 1.6 & 8.17 & 0.90 & & & \\
\hline
\end{tabular}

また表一5の 4 文献 $4 ８ ８ １ 1 ， 17)$ には加熱温度測定值が記載され， その変動幅は $50 \sim 200^{\circ} \mathrm{C}$ 程度であった。したがって CFT柱の載荷加 熱試験結果の考察に際しては，加熱温度の誤差を認識するべきであ ると考えた。なお，表一 599 文献 $5 \sim 7,9,10,12,13,15,19)$ には

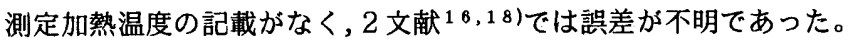
そこで表一5の中で最も多い断面寸法である口-300×9と○-318.5 $\times 9$ について, ISO 834 が許容する範囲内で加熱条件を次のように変 化させて解析的な比較検討を試みた。

(1)加熱温度が一様に低い場合 (下限加熱温度, 3 時間で $1082^{\circ} \mathrm{C}$ )。 (2)標準加熱 (3時間で $\left.1110^{\circ} \mathrm{C}\right)$ 。

(3)加熱温度が一様に高い場合（上限加熱温度，3時間で $1137^{\circ} \mathrm{C}$ )。 (4)断面外周方向の加熱温度に勾配があり，その勾配が標準加熱温 度士 $4.5 \%$ （3時間で $1110 \pm 49^{\circ} \mathrm{C}$ ）の場合。(図一 16 参照) (5)断面外周方向の加熱温度に勾配があり，その勾配が上限加熱温 度士 4.5\%（3時間で $1137 \pm 50^{\circ} \mathrm{C}$ ）の場合。

加熱温度が一様な場合の温度解析は, 角形: $1 / 4$ 断面・二次元, 円
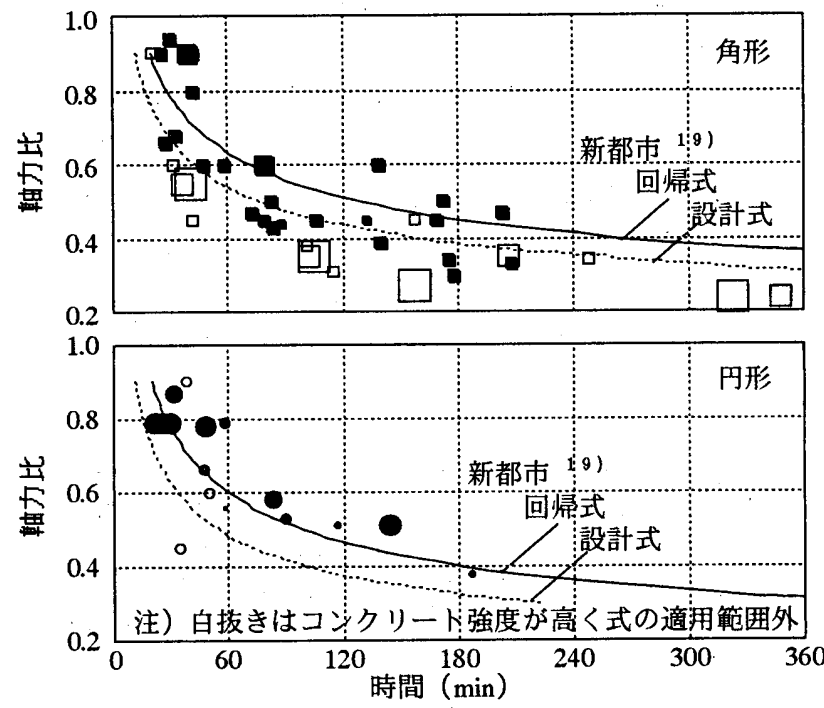

図-13 既往の試験結果

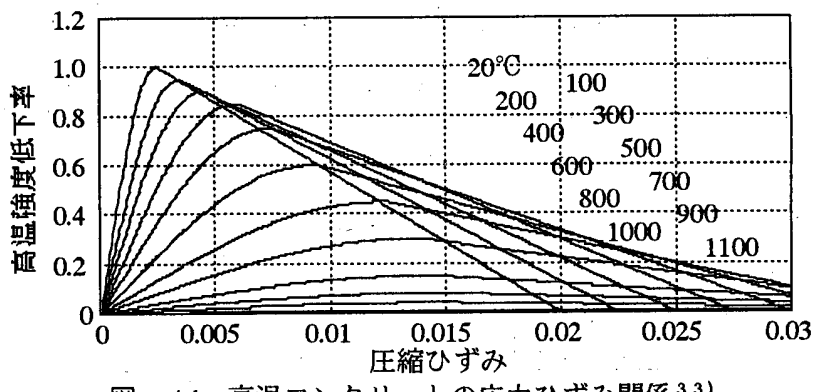

図ー14 高温コンクリートの応むひずみ関係 ${ }^{3}$ 3)

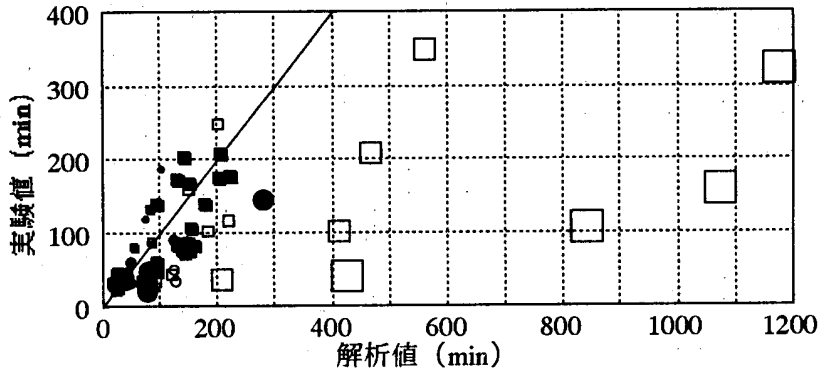

図一 15 耐火時間の実験值と解析值の比較 
形: 一次元, 加熱温度に勾配がある場合の温度解析は, 角形 : 1/2 断 面・二次元, 円形: $1 / 2$ 断面・円柱座標系二次元として，いずれも差 分法で行うこととした。また加熱温度に勾配がある場合は，バイメ タル効果による曲げ変形が部材に生じるので, 図ー16に示すように 部材長 $1,000 \mathrm{~mm} \cdot$ 長さ方向 5 分割・一端固定・他端自由・径長さ比 6.6 の部材を仮定している。

耐火時間の解析值と軸力比の関係を実験値とともに図ー17に示す。 耐火時間の解析值は, 平均加熱温度が下限のときに最も長く, 上限 のときは標準よりも短くなり，標準加熱温度士 $4.5 \%$ おび上限加熱 温度士 $4.5 \%$ ではさらに短くなる。

加熱温度の誤差は一様ではなく, 部材の長さ方向にもあり得るこ となどから, 解析値の帯からはずれている実験値は少なくない。し かし解析值の帯は実験値の分布状況を定性的に説明しており，加熱 温度の誤差が耐火時間のバラッキの重要な一要因であることを明ら かにすることができた。

\section{4. 結論}

概略外形寸法が $300 \cdot 400 \cdot 500 \mathrm{~mm}$ の角形と円形の無耐火被璋 CFT 柱を対象に, 3 時間の加熱試験を行った。その内部温度のシミュレー ション解析を行った結果, コンクリートの熱伝導率をEC4の值の 0.8 倍, 比熱を EC4の值の 1.2 倍，鋼材の熱定数を EC4の值とすること により，解析值が実験值と非常に良く一致することが判明した。

上記温度解析に基づき，コンクリートの熱膨張率・高温強度低下 率・応力ひずみ関係は EC4にしたがって, 弾塑性熱応力解析を行っ た。鋼管の存在は無視し，コンクリートのクリープおよび過渡ひず みは考虑していない。その結果, 既往の無耐火被覆 CFT柱の中心載 荷加熱試験結果のバラツキの重要な一要因が, 加熱温度の誤差にあ ることが明らかとなった。

\section{参考文献}

1) Calculation of the Fire Resistance of Centrally Loaded Composite Steel-Concrete Columns Exposed to the Standard Fire. ECCS, Technical Committee 3, 1988.9（和訳 : JSSCレポート, No.18, 1991）

2) 齊藤 光, 上杉英樹 : 角形鋼管コンクリート柱の耐火試験, 日本建箘学会 大会学術講演梗概集, pp.2107〜 2108，1977.10

3）上杉英樹: 鋼管コンクリート柱の耐火性 (充てんコンクリートの有効性), 日本建勧学会大会学術講演梗概集, pp.2153 2154, 1978.9

4）鈴木敏郎, 木村 衡, 古平章夫, 伏見光雅 : コンクリート充てん角形鋼管 柱の耐火性能に関する実験的研究一定軸力下における加熱時挙動について 一, 日本建築学会構造系論文報告集, 第 350 号, pp.77〜 84, 1985.4

5) 古平章夫, 领塚幸治, 藤中英生, 大橋宏和, 木村 衡: 充填型銅管コンク リート柱の耐火性能についてー中心載荷加熱実験, 日本建築学会大会学術 講演梗概集 B, pp.1051 1052, 1989.10

6) 古平章夫, 藤中英生 : 充填型鋼管コンクリート柱の偏心载荷加熱実験, 日 本建築学会大会学術講演梗概集 B, pp.1043 1044, 1990.10

7) 古平章夫, 藤中英生 : 充填コンクリートを補強した鋼管コンクリート柱の 耐火性能, 日本建築学会大会学術講演梗概集 A-2, pp.99 100, 1995.8

8）佐久間亡, 村松弘道, 吉田正友: 無耐火被覆鋼管コンクリート柱の耐火性 能実験, GBRC, 1987.10

9）今野和近，村松弘道，伊藤茂樹，佐久間仁：無耐火被覆鋼管コンクリート 柱の火炎時耐力の評価, 日本建築学会大会学術講演梗概集 B, pp.1381 $1382,1988.10$

10) 下川弘海, 今野和近, 中村信行, 吉田正友, 伊藤茂樹 : 充填鋼管コンクリー

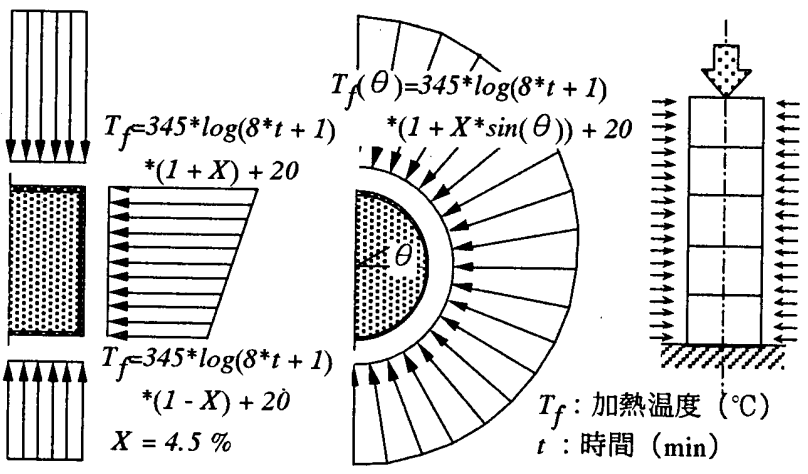

図一 16 勾配のある加熱温度と解析時の軸方向分割

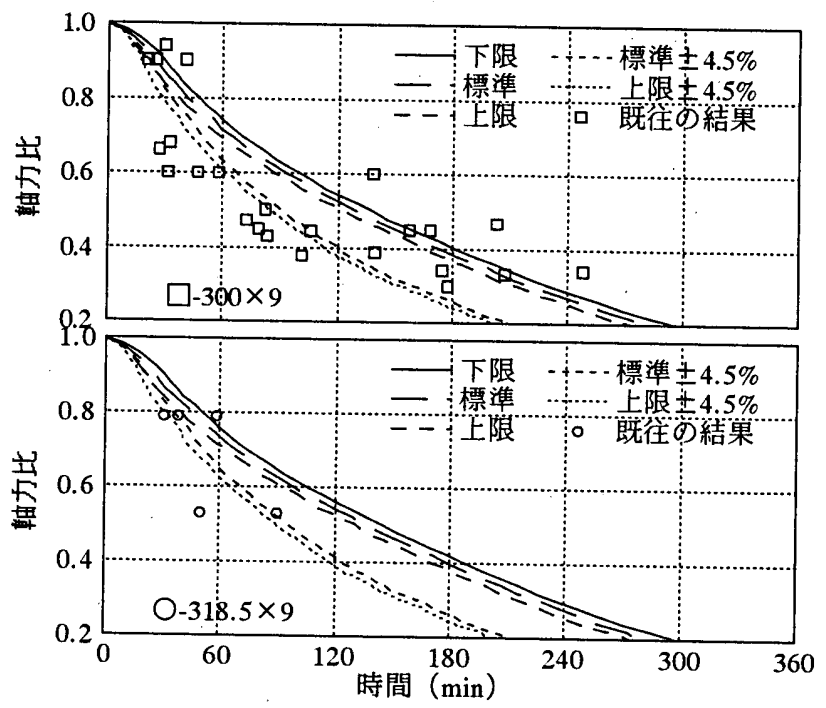

図一 17 軸力比と耐火時間（解析値と実験値）

卜柱の耐火性能に関する研究, 日本建築学会大会学術講演梗概集 A, pp.14017 1422, 1994.9

11）池田䒠一, 熊谷敏男, 中村賢一, 最上浓二, 斎藤 光:アンボンド型充填 鋼管コンクリート構造に関する研究-耐火性能実験-, 日本建築学会大会学 術講演梗概集 B，pp. $557 \sim 558 ， 1989.10$

12）計良光一郎, 作本好文, 山口種美, 岡田忠義 : 建築構造用耐火鋼を使用し たコンクリート充填鋼管実大柱の載荷加熱試験, 日本建築学会大会学術講 演梗概集 B, pp.1041 1042，1990.10

13）作本好文, 山口種美, 岡田忠義, 吉田正友, 田坂茂樹 : 建築構造用耐火鋼 を使用した鋼管コンクリート柱の耐火性能に関する実験的研究,日本建筑 学会構造系論文報告集，第 447 号, pp.159 168，1993.5

14）道越真太郎, 西垣太郎, 水野敬三, 黒岩秀介, 後藤和正, 前沢澄夫, 塚田 康夫, 斎藤光, 上杉英树, 中村賢一: 大断面コンクリート充填鋼管柱の耐 火性に関する研究, 日本建築学会大会学術講演梗概集A, pp.1407 1410, 1994.9

15）道越真太郎, 西垣太郎, 黒羽健嗣, 水野敬三, 黒岩秀介, 斎藤光, 上杉英 樹，中村賢一 : コンクリート充填型鋼管柱の雨火性に関する研究-火炎時 の軸方向支持力, 日本建築学会大会学術講演梗概集A-2,pp.89 90, 1995.8

16）杉田和直, 道越真太郎, 西垣太郎: 高強度コンクリート充填鋼管柱の利火 性能実験, 日本建築学会大会学術講演梗概集 A-2, pp.19 24, 1998.9

17）吉野茂, 畑戸龍夫, 多賀章, 今村輝武：無耐火被腹鋼管コンクリート柱の 耐火性能-中心載荷加熱実験, 日本建策学会大会学術講演梗概集B, Pp. 1425 $\sim 1426,1994.9$

18）久保田一男, 高田啓一, 平山博巳 : 鉄筋コンクリート充填型鋼管柱の耐火 性能の検討, 日本建築学会大会学術講演梗概集 A-2, pp.101 102, 1995.8 19）新都市ハウジング協会: CFT構造技術指針・同解説, 2000年度版, 2001.2 
20）齊藤秀人，齋藤 光：充填鋼管コンクリート柱の耐火性能に関する実験的 研究一梁の伸び出しによる強制変形を受ける場合についてー,日本建築学 会構造系論文報告集 No.458, pp.163 169，1994.4

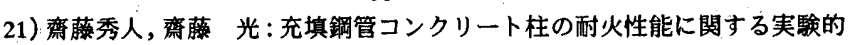
研究一梁の伸び出しによる横力を受ける場合について一,構造工学論文集 Vol.46B, pp.221 227, 2000.3

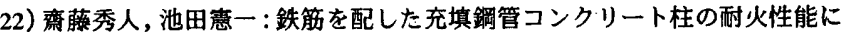
関する実駼的研究一梁の伸び出しによる横力を受ける場合についてー, 日 本建築学会構造系論文報告集 No.549, pp.151～157, 2001.11

23）谷田貝健，齋藤秀人, 上杉英樹, 齋藤 光 : コンクリート充填型鋼管柱の 耐火性一数值解析による応力変形性状一, 日本建築学会大会学術講演梗概 集 A, pp.1399 1400, 1992.8

24）谷田貝健, 齋藤秀人, 上杉英树, 齋藤 光: 円形断面を持つコンクリート 充填型鋼管柱の耐火性一数值解析による応力変形性状一, 日本建筑学会関 東支部研究報告集, pp.209 212, 1993.3

25）丹羽博則，谷田貝健，斎藤秀人，上杉英傠，斎藤 光: コンクリート充填 型鋼管柱の耐火性一軸方向変形量の補正方法の検討一, 日本建築学会大会 学術講演梗概集 A, pp.1367 1368, 1993.9

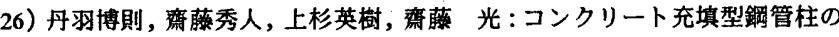
耐火性一鋼管の局部座届を考慮した解析一, 日本建築学会大会学術講演梗 概集 A，pp.1413～1414，1994.9

27）齋藤秀人, 森田武 : 無耐火被復充填鋼管コンクリート柱の耐火性能につい て (その $4 \cdot 5)$, 日本建策学会大会学術講演梗概集 A-2, pp.1 2, 2002.8, pp.261 262, 2003.9

28）柴田道生 : コンクリート充填鋼管の火災時の温度分布, 日本建策学会大会
学術講演梗概集 A, pp.1431～1432，1994.9

29）日本建築学会 : コンクリート充填鋼管構造設計施工指針，1997.10

30）原田有：建築耐火構法, 工業調查会, 1973

31)H. Bizri :Structural Capacity of Reinforced Concrete Columns Subjected to Fire Induced Thermal Gradients, Report No. UC SESM 73-1, University of California Berkeley, January 1973

32) Juri Kajaste-Rudnitski : Numerical model of thermoelastic-plastic concrete material, VTT publications 154, Technical Research Centre of Finland, September 1993

33) Eurocode 4, Design of Composite Steel and Concrete Structures, Draft for Part 1.2 : Structural Fire Design, 1994

34）日本建策センター：建築物の総合防火設計法 第 4 巻 耐火設計法, 1988.4

35) ISO 834-1 : Fire-resistance tests - Elements of building construction -, Part : General requirements, 1999

36）日本建築学会 : 鋼構造耐火設計指針，1999.1

37）日本工業規格：JIS A 1304 建築構造部分の耐火試験方法, 1994

38）大内富夫, 湯谷孝夫, 西垣太郎, 丹羽博則, 宮本圭一, 斎藤秀人, 谷田貝 健, 高橋済: 建築構造物の長期設計荷重時応力; 日本建築学会大会学術講 演梗概集 A-2, pp.165 170, 1997.9

39）上杉英樹，小池 浩: 高層鉄骨架構の熱応力解析（その1）区画火災を受 ける高層鉄骨架構の熱応力解析手法, 日本建築学会構造系論文報告集 No.384, pp.1 12, 1988.2

40）上杉英树，関美和，丹羽博則，斎藤 光: 火災時に於けるコンクリート充 填鋼管柱の荷重支持能力に関する解析的研究，構造工学論文集 Vol.42B, pp.379 386, 1996.3 